\title{
Anxiolytic Potentials of Artocarpus altilis (Breadfruit) in Swiss Mice
}

\author{
Ajah AA ${ }^{1,2}$, Onasanwo SA ${ }^{1 *}$, Aitokhuehi NG ${ }^{1}$ and \\ Faborode OS $^{1,3}$ \\ ${ }^{1}$ Department of Physiology, University of Ibadan, Nigeria \\ ${ }^{2}$ Department of Physiology, University of Port-Harcourt, \\ Nigeria \\ 32Department of Human Physiology, Bingham University, \\ Nigeria \\ *Corresponding author: Onasanwo SA, Neurosciences \\ and Oral Physiology Unit, Department of Physiology, \\ Faculty of Basic Medical Sciences, College of Medicine, \\ University of Ibadan, Nigeria
}

Received: November 20, 2017; Accepted: December 22, 2017; Published: December 29, 2017

\begin{abstract}
Artocarpus altilis, commonly known as bread fruit, is a plant known for its various therapeutic activities including antibacterial, antitumor, antimicrobial, pains. Moreover, folklore has it that the plant concoction is taken to alleviate mood swing. However, no work has been reported on its anti-anxiety properties. Therefore, anxiety-like effects of Artocarpus altilis was evaluated in mice.
\end{abstract}

The air-dried leaf of Artocarpus altilis pulverized and macerated in methanol for 72 hours and was filtered to obtain the crude methanol extract. The anxiolytic-like effect of MEAA was investigated using the Elevated Plus Maze (EPM), Elevated Zero Maze (EZM) and Light-Dark Test (LDT). The extract was administered orally to the animals.

Artocarpus altilis showed anxiolytic-like effect in mice, $200 \mathrm{mg} / \mathrm{kg}$ were significantly different $(p<0.05)$ from the control by the time spent in the open arms in elevated plus maze and elevated zero maze, and $100 \mathrm{mg} / \mathrm{kg}$ and $200 \mathrm{mg} / \mathrm{kg}$ were significantly different $(p<0.05)$ in time spent in light chamber in the light-dark test.

In conclusion, Artocarpus altilis may possess anxiolytic-like properties.

Keywords: Artocarpus altilis; Anxiety; Elevated plus maze; Elevated zero maze; Light-dark test

\section{Introduction}

Global records show that approximately 450 million people suffer from a mental or behavioural disorder [1]. However, only a small number gets the most basic treatment. This corresponds to about $12.3 \%$ of the global burden of disease, which is estimated to rise to $15 \%$ by 2020 [2]. Anxiety disorders are a group of mental disorders characterized by feelings of anxiety and fear, where anxiety is a worry about future events and fear is a reaction to current events [3]. Anxiety disorders appear to be caused by an interaction of bio psychosocial factors, including genetic vulnerability, which interact with situations, stress, or trauma to produce clinically significant syndromes. [4].

In the search for new therapeutic products for the treatment of neurological disorders, medicinal plant research, worldwide, has progressed constantly, demonstrating the pharmacological effectiveness of different plant species in a variety of animal models [5]. These include Vernonia amygdalina, Chebulinic acid, Buchholzia coriacea [6-8], Salvia elegans [9], Kaempferiaparviflora [10] among many others.

Artocarpus altilis (Parkinson) Fosberg (Moraceae) is a tree of moderate size and is widely cultivated in tropics as staple crop. It originates from A. camansi Blanco and A. marianmensistrecul [11]. Breadfruit is a versatile food that can be cooked and eaten at all stages of its development. Some biological activities have been reported to include hemolytic activity (leaves); antibacterial (root bark); antitumour [12] and antimicrobial [13]. Research has also shown the presence of a number of active compounds: the fruit contains artocarpine and the enzyme papayotine; the leaf contains the phenols quercetin and camphorol, plus gamma-aminobutyric acid, which lowers the blood pressure [14]. Traditionally, breadfruit has been used in the treatment of chest pains, pain in the bones, painful breathing, and stomach aches $[15,16]$. Despite all these neurological medicinal properties, there has not been any study investigating its anxiolytic potentials.

We therefore investigated the anxiolytic effects of Artocarpus altilis (Breadfruit) in laboratory Swiss mice.

\section{Materials and Methods}

\section{Plant preparation and extraction}

Fresh fruit seeds (10 kg) of Artocarpus altilis (breadfruit) were collected, identified and authenticated at Forestry Research Institute of Nigeria (FRIN) Ibadan, Nigeria, with a Forestry Herbarium Identification Number 110483. The fresh fruit seed of Artocarpus altilis (breadfruit) were air dried at room temperature, after which they were pulverized. The pulverized breadfruit was soaked methanol for 72 hours. The mixture was filtered and the filtrate was concentrated using a rotary evaporator at a maximum temperature of $40^{\circ} \mathrm{C}$ to obtain the crude extract, which was later kept in the refrigerator at $4^{\circ} \mathrm{C}$ for further use. The methanol extract was subsequently reconstituted in normal saline at appropriate concentration, and administered orally.

\section{Experimental animals and treatment}

Adult male Swiss mice weighing 20-25 g were used in this study and were obtained from the Animal House, College of Medicine, University of Ibadan, and Ibadan, Nigeria. The animals were kept 


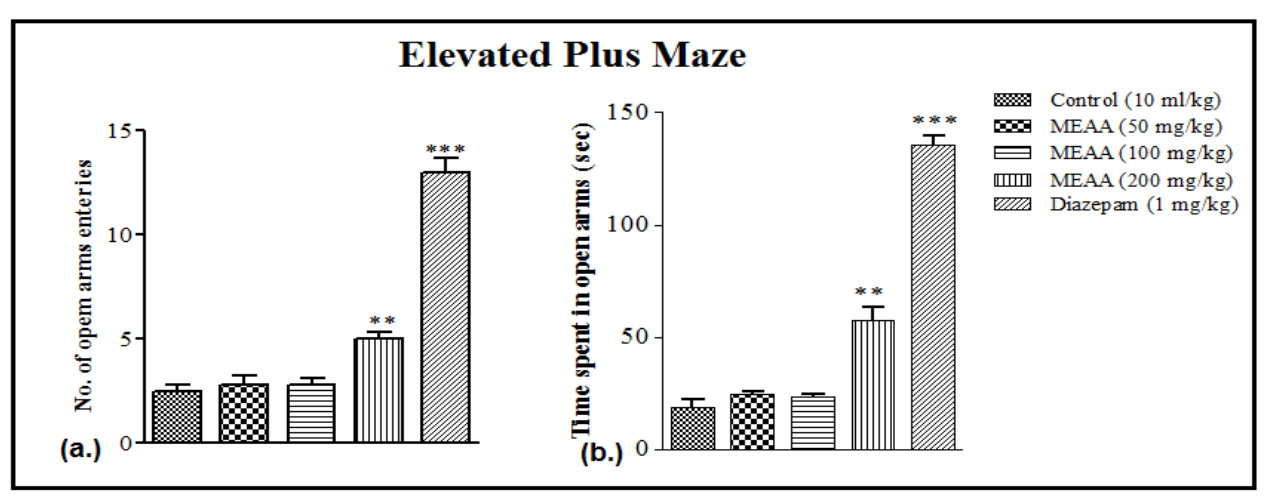

Figure 1: Effect of Methanol extract of Artocarpus altilis (MEAA) administration on (a) number of open arm entries and (b) time spent in open arms in Elevated Plus Maze (EPM). The results were expressed as means \pm SEM. Data were analysed using One-way ANOVA followed by Newman-Keuls' post hoc test. ** $p<0.01$, $\star * * p<0.001$ compared with the control $(\mathrm{n}=6)$.

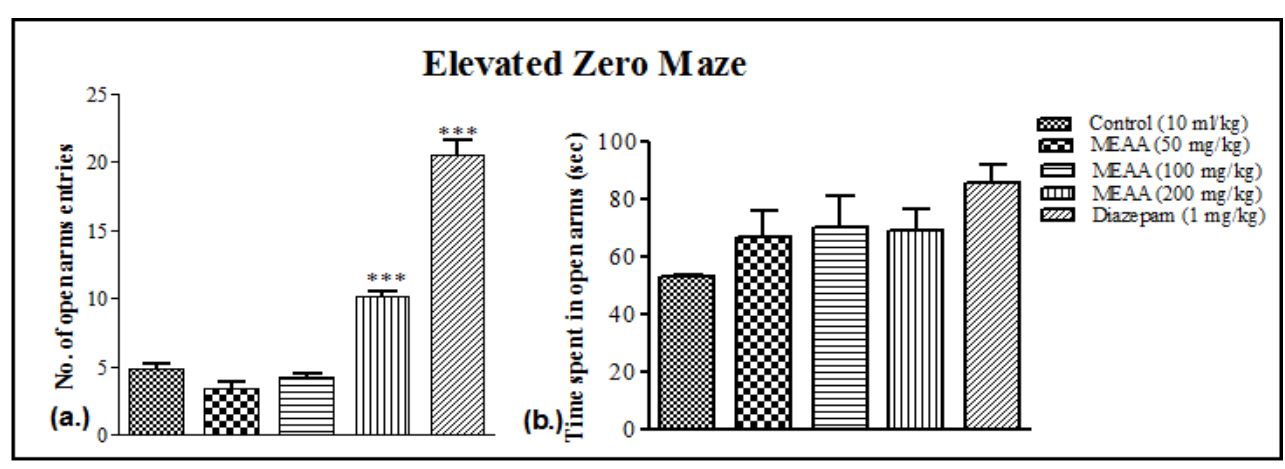

Figure 2: Effect of Methanol extract of Artocarpus altilis (MEAA) administration on number of (a) open arms entries and (b) time spent in open arms in Elevated Zero Maze (EZM). The results are expressed as means \pm SEM. Data were analysed using One-way ANOVA followed by Newman-Keuls' post hoc test. *** $p<0.001$ compared with the control $(n=6)$.

under a conducive environmental condition, and fed with standard rodent pellet and water ad libitum. Animals were divided into four groups and treated as follows: Group 1 received Normal Saline at $10 \mathrm{ml} / \mathrm{kg}$, p.o), Groups 2, 3 and 4 received oral administration of Methanol Extract of Artocarpus Altilis (MEAA) at $50 \mathrm{mg} / \mathrm{kg}, 100 \mathrm{mg} /$ $\mathrm{kg}$ and $200 \mathrm{mg} / \mathrm{kg}$ respectively, while Group 5 received Diazepam at $1 \mathrm{mg} / \mathrm{kg}$, p.o. Test was carried out 1 hour after administration of either vehicle or MEAA, while test was carried out 30 minutes after diazepam administration. The experimental procedures adopted in this study were in accordance with the United States National Institutes of Health Guidelines for Care and Use of Laboratory Animals in Biomedical Research [17].

\section{Anxiety experimental models}

Elevated Plus Maze (EPM): This test has been widely used and validated to measure anxiety in rodents [18]. The apparatus was designed with some modifications for mice. It is composed of two open arms, $30 \times 5 \mathrm{~cm}$, and two closed arms, $30 \times 5 \times 10 \mathrm{~cm}$, with an open roof, arranged such that the two open arms were opposite to each other, and radiated from a central platform to form a plus sign. The platform was elevated to a height of $45 \mathrm{~cm}$ above the floor level. Each animal was placed on the centre of the platform, facing one of the closed arms. The number of entries and the time spent in the open and closed arms was recorded during a 5-minute test period by a trained observer blind to the treatment given. The apparatus was cleaned thoroughly between trials with $10 \%$ ethanol solution and dry towels to remove any remaining moisture.

Elevated Zero Maze (EZM): The standard zero plus maze is a variation of the elevated plus maze used to assess anxiety-like behaviour in small laboratory animals (rat/mice). As in the elevatedplus maze, this test is based on two conflicting innate tendencies: exploring a novel environment and avoiding elevated and open spaces constituting situations of predator risk. The apparatus consisted of two open and two enclosed elevated arms that form a zero or circle with a sequence, open-close-open-close. The distances between the arms are equal. It was designed according to the following dimensions: elevated height of platform above ground $(45 \mathrm{~cm})$; height of closed arms $(15 \mathrm{~cm})$; outer diameter of circle platform (45 $\mathrm{cm})$; inner diameter of circle platform $(33 \mathrm{~cm})$, and this leaves a $5 \mathrm{~cm}$ width which serves as the walking arena between the closed and open arms. The number of times and time spent in each arms of the maze were recorded during a 5-minute test session by a trained observer blind to the treatment given. The apparatus was cleaned thoroughly between trials with $70 \%$ ethanol solution and dry towels to remove any residue or unpleasant odour.

Light-Dark test: This model consisted of a Plexi glass box with two compartments $(20 \times 20 \times 20 \mathrm{~cm}$ each), one of which was illuminated with a white light while the other remained dark. Each animal was placed at the junction of the light dark, facing the illuminated 


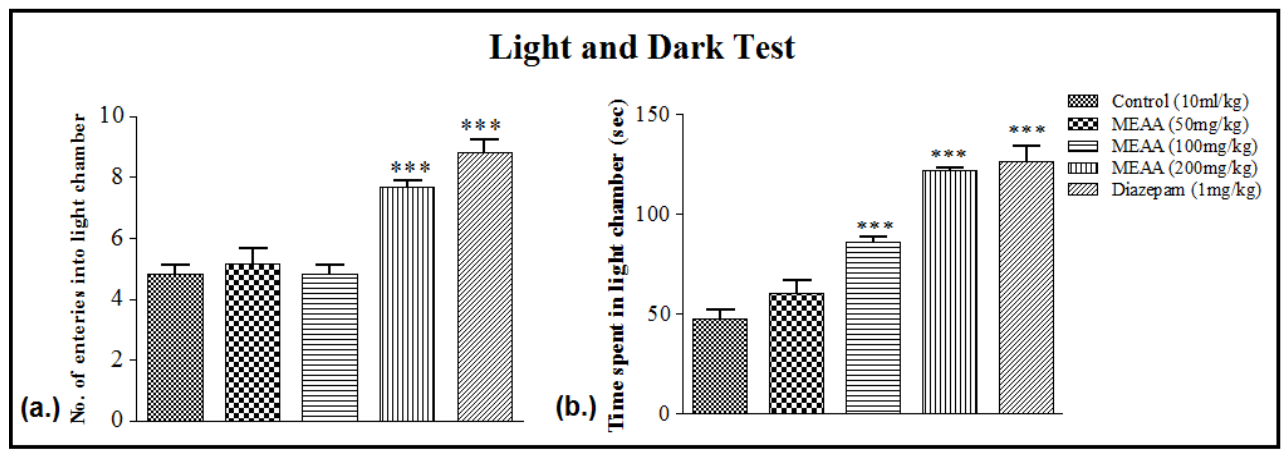

Figure 3: Effect of Methanol extract of Artocarpus altilis (MEAA) administration on (a) number of entries and (b) time spent in light chamber in light chamber in Lightdark Test (LDT). The results are expressed as means \pm SEM. Data were analysed using One-way ANOVA followed by Newman-Keuls' post hoc test. *** $<<0.001$ compared with the control $(n=6)$.

compartment. The time spent in illuminated chamber, as well as the number of entries in each space was recorded for 5 minutes by a trained observer blind to the treatment given [19]. After each test, the box was carefully cleaned with $10 \%$ ethanol solution and dry towels to remove any residue or unpleasant odour.

\section{Statistical analysis}

The results obtained were expressed as mean \pm SEM. Variance was analysed using One-way Analysis of Variance (ANOVA), followed by Newman- Keuls' multiple comparisons test. Statistical significance was set at $P<0.05$. All statistical analyses were done using Graph Pad Prism Software, Version 5 (San Diego, CA, USA).

\section{Results and Discussion}

This study was aimed to elucidate the behavioural effects of Methanol Extract of Artocarpus Altilis (MEAA), a plant known for its various therapeutic potentials in most part of the world [20]. It was seen in this study that MEAA demonstrated anxiolytic like effect in mice.

\section{Elevated plus Maze}

Methanol Extract of Artocarpus Altilis (MEAA) at the dose of 200 $\mathrm{mg} / \mathrm{kg}$ only caused a significant increased the number of open arms exploration $\left({ }^{*} p<0.01\right)$ when compared with the control. Diazepam $(1 \mathrm{mg} / \mathrm{kg})$ which served as a positive control drug also significantly increased the number of open arms exploration $\left({ }^{* * *} p<0.001\right.$ respectively) when compared with the control (Figure 1a).

As shown in Figure 1b, MEAA at the dose of $200 \mathrm{mg} / \mathrm{kg}$ and diazepam $(1 \mathrm{mg} / \mathrm{kg})$ produced significant increase $\left({ }^{* *} p<0.01\right.$ and ${ }^{* * *} p<0.001$ respectively) in the time spent in the open arms of the Elevated Plus Maze when compared with the control.

Elevated Plus Maze (EPM) used is a widely used model in the assay for anxiety status of rats and mice, it is based on mice's aversion for open spaces. This aversion leads to the behaviour termed as thigmotaxic, which means avoidance to open areas by restricting movements to enclosed spaces or to the edges of a confined space. Increased amount of time spent in the closed arms during a 5-minute test session is indicative of high anxiety-like behaviour. In this study, the frequency of entries and the amount of time MEAA-treated mice spent in the open arms was higher than the control, indicating an anxiolytic action. This is in line with the findings of previous work which state that increase in the number of entries into the open arms in EPM similar to that of the standard drug (Diazepam) depicts antianxiety activity $[21,22]$.

\section{Elevated zero maze}

The oral administration of Methanol Extract of Artocarpus altilis at dose of $200 \mathrm{mg} / \mathrm{kg}$ significantly increased $\left({ }^{* *} p<0.001\right)$ number of open arms entries in Elevated Zero Maze as when compared with the control. Similarly, diazepam $(1 \mathrm{mg} / \mathrm{kg})$ also showed significant increase $\left.{ }^{* * *} p<0.001\right)$ in number of open arms entries when compared with the control (Figure 2a).

Administration of Methanol Extract of Artocarpus altilis, vehicle or diazepam did not show any significant differences in the amount of time spent in open arms during the Elevated Zero Maze test (Figure 2b).

Similarly, animals treated with MEAA had a higher frequency in the number of entries into the open arms of the Elevated Zero Maze (EZM). The amount of time spent in the open arms was also higher than the control, indicating an anxiolytic action. EZM was created to eliminate the centre region of the EPM, and has also been pharmacologically validated with anxiolytic drugs [23]. Animals are found to spend $13 \%$ to $30 \%$ of their test time in the centre of the EPM, thereby decreasing the time spent in open or closed areas by 39-90 s of the total 300 s test session [24].

\section{Light-Dark test}

Methanol extract of Artocarpus altilis (200 mg/kg) and diazepam $(1 \mathrm{mg} / \mathrm{kg})$ increased significantly $\left({ }^{* *} p<0.001\right)$ the number of entries into the light chamber when compared with the control (Figure $3 \mathrm{a}$ ).

However, two graded doses of Methanol extract of Artocarpus altilis $(100 \mathrm{mg} / \mathrm{kg}$ and $200 \mathrm{mg} / \mathrm{kg})$ produced significant increase $\left.{ }^{* * *} p<0.001\right)$ in total time spent in light chamber when compared with the saline-treated group. Positive control group treated with Diazepam $(1 \mathrm{mg} / \mathrm{kg})$ produced significant increase $\left({ }^{* *} p<0.001\right)$ in total time spent in light chamber when compared with the salinetreated group, as revealed by One-way ANOVA (Figure 3b).

In the light-dark test, the time spent in the light compartment and numbers of entries into the light compartment were used as an index of the anxiety state of mice [25]. It has the advantages of being quick and easy to use, without the prior training of animals, food and water 
deprivation is unnecessary and natural stimuli are used. Again, our extract increased the number of entries into the light region and time spent in the light chamber, which indicate an anxiolytic effect. These changes were also similar to the effects of standard drug used.

The anxiolytic properties observed in the three animal models used in this study might be as a result of some bioactive molecules which the plant has been shown to possess. A notable example is Gamma Amino Butyric Acid (GABA). Standard anxiolytic (e.g. diazepam) drugs are known to act via the GABA pathway [26]. However, further data are required to confirm this hypothesis.

\section{Conclusion}

Breadfruit (Artocarpus altilis) possesses anxiolytic-like effect in elevated plus maze, elevated zero maze and light-dark test model. These therefore reinforce its neuro-ethnopharmacological importance to include anxiety. Additional works are required to fully elucidate the involvement of active constituents of the plant responsible for the anxiolytic effects.

\section{References}

1. World Health Organization. 2001.

2. Reynolds EH. Brain and mind: a challenge for WHO. Lancet. 2003; 361: 1924-1925.

3. Diagnostic and Statistical Manual of Mental Disorders American Psychiatric Association. ( $5^{\text {th }}$ edn). Arlington: American Psychiatric Publishing. 2013; 189 195.

4. Freitas-Ferrari MC, Hallak JE, Trzesniak C, Filho AS, Machado-de-Sousa $\mathrm{JP}$, Chagas $\mathrm{MH}$, et al. Neuroimaging in social anxiety disorder: a systematic review of the literature. ProgNeuropsychopharmacolBiol Psychiatry. 2010; 34: $565-580$.

5. Zhang ZJ. Therapeutic effects of herbal extracts and constituents in animal models of psychiatric disorders. Life Sci. 2004; 75, 1659-1699.

6. Onasanwo SA, Obembe OO, Faborode SO, Elufioye TO, Adisa RA. Neuropharmacological potentials of Buchholzia coriacea (Engl.) seeds in laboratory rodents. Afr J Med Med Sci. 2013; 42: 131-142.

7. Onasanwo SA, Faborode SO, Agrawal M, ljiwola OL, Jaiyesimi BO, Narende T. Antidepressant and Anxiolytic Potentials of Chebulinic Acid in Laboratory Rodent. Ann Depress Anxiety. 2014; $1: 5$.

8. Onasanwo SA, Aitokhuehi NG, Ajayi TO, Faborode SO. The Anxiolytic properties of Vernonia amygdalina (Asteraceae) in Laboratory Mice. Afr J Biomed. Res. 2016; 19: 229-233.

9. Herrera-Ruiz M, Garcia-Beltran Y, Mora S, Dıaz-Veliz G, Viana GSB, Tortoriello J, et al. Antidepressant and anxiolytic effects of hydroalcoholic extract from Salvia elegans. J Ethnopharmacol. 2006; 107: 53-58.
10. Jintanaporn W, Prasert P, Kittisak S, Supaporn M, Bungorn S. Evaluation of the Anxiolytic and Antidepressant Effects of Alcoholic Extract of Kaempferiaparviflora in Aged Rats. American Journal of Agricultural and Biological Science. 2007; 2: 94-98.

11. Zerega NCJ, Mortley TJ. Artocarpus (moraceae) molecular phylogeny-the systematic \& origins of Bread fruit (Artocarpus altilis). Botanical society of America's annual meeting. Albuquerque NM. 2001.

12. Sundar Rao K, et al. Int J Pharmacog. 1993; 31: 3-6.

13. Jalal TK, Ahmed IA, Mikail M, Momand L, Draman S, Isa ML, et al. Evaluation of antioxidant, total phenol and flavonoid content and antimicrobial activities of Artocarpus altilis (breadfruit) of underutilized tropical fruit extracts. Appl Biochem Biotechnol. 2015; 175: 3231-3243.

14. Lachman-White DA, Adams CD, Trotz UO. A Guide to the Medicinal Plants of Coastal Guyana. Commonwealth Science Council. 1987; 350.

15. Weiner MA. Econ Bot. 1971; 25: 423-450.

16. Whistler WA. J Ethnopharmacol. 1985; 13: 239-280.

17. National Institute of Health. "Animals in Research". Health Research Extension Act of 1985. Public Law. 1985: 99-158.

18. Pillow S, Chopin P, File SE, Briley M. Validation of open: closed arm entries in an elevated plus-maze as a measure of anxiety in the rat. J Neurosci Methods. 1985; 14: 149-167.

19. Crawley J, Goodwin FK. Preliminary report of a simple animal behavior model for the anxiolytic effects of benzodiazepines. Pharmacol Biochem Behav. 1980; 13: 167-170.

20. Morton JF, Breadfruit. Artocarpusaltilis. In: Fruits of warm climates. Miami FL.1987; 50-58.

21. Pellow S, File SE. Anxiolytic and anxiogenic drug effects on exploratory activity in an elevated plus-maze: a novel test of anxiety in the rat. PharmacolBiochemBehav. 1986; 24: 525-529.

22. Budzynska B, Anna B, Marta K, Krystyna S, Agnieszka M, Irena M, et al. Effects of imperator in on nicotine-induced anxiety- and memory-related responses and oxidative stress in mice. Physiol Behav. 2013; 122: 46-55.

23. Shepherd JK, Grewal SS, Fletcher A, Bill DJ, Dourish CT. Behavioral and pharmacological characterisation of the elevated "zero-maze" as an animal model of anxiety. Psychopharmacology (Berl). 1994; 116: 56-64

24. Braun AA, Skelton MR, Vorhees CV, Williams MT. Comparison of the elevated plus and elevated zero mazes in treated and untreated male Sprague-Dawley rats: Effects of anxiolytic and anxiogenic agents. Pharmacol Biochem Behav. 2011; 97: 406-415.

25. Suzuki, TA, Mitsuyuki BS, Sakaue GN, Shinya I, Takaya S, Masahiko M Takashi. Anesthesia \& Analgesia. 2007; 104: 1570-1577.

26. Date SK, Hemarathi KG, Gulati OD. Investigation of the muscle relaxant activity of nitrazepam. Arch Int Pharmacodyn Ther. 1984; 272: 129-139.
Ann Depress Anxiety - Volume 4 Issue 2 - 2017

ISSN : 2381-8883 | www.austinpublishing group.com

Onasanwo et al. (C) All rights are reserved
Citation: Ajah AA, Onasanwo SA, Aitokhuehi NG and Faborode OS. Anxiolytic Potentials of Artocarpus altilis (Breadfruit) in Swiss Mice. Ann Depress Anxiety. 2017; 4(2): 1089 